

\title{
SURVEI TINGKAT KEBUGARAN JASMANI ATLET KARATE DOJO REDLAND HALONG USIA 16 - 19 TAHUN DALAM PERSIAPAN KEJURDA REDLAND II 2019 DI AMBON
}

Jefry Dulanlebit

SMA Negeri 3 Ambon, jefridulanlebit@gmail.com

\begin{abstract}
ABSTRAK
Tujuan penelitian ini adalah untuk mengetahui tingkat kebugaran jasmani atlet Karate Dojo Redland Halong Usia 16 - 19 Tahun. Populasi dalam penelitian ini adalah Atlet Karate Dojo Redland Halong sebanyak 30 orang. Teknik pengambilan sampel dengan menggunakan metode purposive sampling. Sampel dalam penelitian ini adalah Atlet Karate Dojo Redland Halong sebanyak 30 orang yang berusia 16-19 tahun. Instrumen yang digunakan untuk mengukur kebugaran jasmani dalam penelitian ini adalah Tes Kebugaran Jasmani Indonesia (TKJI). untuk 16-19 tahun. Analisis data menggunakan analisis uji t (paired sample t test) pada taraf signifikasi $5 \%$ dengan aplikasi SPSS ver 16. Berdasarkan analisis menunjukkan bahwa: Tingkat Kebugaran Jasmani atlet Karate Dojo Redland Halong yang berkategori baik sekali 0 orang atau $0 \%$, baik 18 orang atau $60 \%$, sedang 12 orang atau $40 \%$, kurang 0 orang atau $0 \%$ dan kurang sekali 0 orang atau $0 \%$. secara keseluruhan diketahui atlet putra yang memperoleh data baik sekali 0\% (0 atlet), baik 67\% (10 atlet), sedang sebanyak 33\% (5 atlet), kurang 0\% (0 atlet), kurang sekali 0\% (0 atlet).
\end{abstract}

Kata Kunci: Tingkat Kebuigaran jasmani 


\section{A. PENDAhuluan}

Kebugaran jasmani adalah kesanggupan dan kemampuan tubuh melakukan penyesuaian terhadap pembebanan fisik yang diberikan seseorang dari kerja yang dilakukan sehari-hari tanpa menimbulkan kelelahan yang berlebihan dan masih mempunyai cadangan tenaga untuk melakukan kegiatan lainnya. Setiap orang membutuhkan kebugaran jasmani yang baik agar ia dapat melakukan pekerjaannya dengan efektif dan efisien tanpa mengalami kelelahan yang berarti.

Pengkondisian jasmani (physical conditioning) memegang peranan yang sangat penting untuk mempertahankan atau meningkatkan derajat kebugaran jasmani (physical fitness) (Khalili Moghaddam \& Lowe, 2019). Derajat kebugaran jasmani seseorang sangat menentukan kemampuan fisiknya dalam melaksanakan tugas-tugasnya sehari-hari. Kian tinggi derajat kebugaran jasmani seseorang kian tinggi pula kemampuan kerja fisiknya. Dengan kata lain, hasil kerjanya kian produktif jika kebugaran jasmaninya kian meningkat. Selain berguna untuk meningkatkan kebugaran jasmani, latihan kondisi fisik merupakan program pokok dalam pembinaan atlet untuk berprestasi dalam suatu cabang olahraga. Menurut (Juniar \& Dr. Wijono, 2019) olahraga karate diperlukan tingkat kondisi fisik yang sangat baik. Selain mental, teknik, dan taktik kondisi fisik menjadi hal yang sangat penting untuk meningkatkan prestasi atlet.

Kondisi fisik dipandang sebagai hal yang fundamental bagi atlet, karena tanpa dukungan kondisi fisik yang prima maka pencapaian prestasi maksimal akan sulit terwujud. Karate adalah cabang olahraga dengan gerakan kompleks, maka dibutuhkan beberapa komponen kondisi fisik. Komponen kondisi fisik yang dibutuhkan oleh seorang karateka saat bertanding adalah antara lain : Kekuatan, Kecepatan, Kelincahan, Daya Tahan, Kelentukan, Koordinasi, Ketepatan, dan Reaksi.

Sesuai dengan pengamatan yang peneliti amati pada performance atlet karate Dojo Redland Halong pada saat bertanding di ajang XION CUP Tahun 2018 di Sport Hall Karang Panjang Ambon, terkait implementasi pada teknik saat bertanding cukup buruk, hasil yang diperoleh pada atlet kelas kadet yang selalu mendapat mendali emas tetapi di even ini tidak bisa membawa mendali emas sama sekali, faktor menurunnya kualitas atlet dilihat dari beberapa teknik seperti pukulan gyaku yang tak memiliki power dan pukulan kisame yang lambat menjadi faktor utama dalam performace atlet saat bertanding. Selain itu kondisi fisik atlet yang tidak prima seperti atlet yang lelah sebelum pertandingan usai juga menjadi faktor turunnya prestasi atlet karate Dojo Redland Halong.

Dengan mengacu pada realita di atas maka peneliti tertarik untuk melakukan penelitian dan menjadikan sebagai dasar pikir untuk mengangkat permasalahan ini dengan judul : "Survei Tingkat Kebugaran Jasmani Atlet Karate Dojo Redland Halonh Usia 16-19 Tahun Dalam Persiapan Kejurda Redland II 2019 Di Ambon”.

\section{B. METODE PENELITIAN}


Penelitian ini merupakan penelitian deskriptif kuantitatif tentang status kebugaran atlet Karate Dojo Redland dengan satu variabel tanpa membuat perbandingan dan menghubungkan dengan variabel lainnya. Penelitian deskriptif tidak dimaksudkan untuk menguji hipotesis tertentu, tetapi hanya menggambarkan apa adanya tentang suatu variabel, gejala atau keadaan (Sugiyono, 2015). Metode yang digunakan dalam penelitian ini adalah metode survei. Teknik pengumpulan data dengan tes pengukuran.

\section{POPUlaSi DAN SAMPEL PENELITIAN}

Dalam pengambilan sampel peneliti menggunakan Teknik Purposive Sampling karena Metode ini menggunakan kriteria yang telah dipilih oleh peneliti dalam memilih sampel. Kriteria pemilihan sampel terbagi menjadi kriteria inklusi dan eksklusi. Populasi dalam penelitian ini adalah Atlet Karate Dojo Redland Halong sebanyak 30 orang yang terdiri dari 15 Putra dan 15 Putri sehingga ini dilakukan pada populasi.

\section{INSTRUMEN PENELITIAN}

Instrumen yang digunakan untuk mengukur kebugaran jasmani dalam penelitian ini adalah Tes Kebugaran Jasmani Indonesia (TKJI) (Rahmat \& Permana, 2016) untuk 16-19 tahun yang sudah dibakukan yang terdiri atas 5 tes yaitu:

1. Lari 60 meter

Tes ini bertujuan untuk mengukur kecepatan. Hasil yang dicatat adalah waktu yang dicapai oleh pelari untuk menempuh jarak 60 meter, dalam satuan detik.

2. Tes angkat tubuh (pa) dan gantung siku tekuk (pi)

Tes ini bertujuan untuk mengukur kekuatan dan daya tahan otot lengan dan otot bahu. Untuk putra hasil yang dicatat adalah jumlah angkatan yang sempurna yang dilakukan, sedangkan untuk putri hasil yang dicatat adalah waktu yang dicapai oleh peserta untuk mempertahankan sikap tersebut dalam satuan detik.

3. Tes baring duduk

Tes ini bertujuan untuk mengukur kekuatan dan daya tahan otot perut. Hasil yang dihitung dan dicatat adalah jumlah gerakan baring duduk yang dapat dilakukan dengan sempurna selama 60 detik.

4. Tes loncat tegak

Tes ini bertujuan untuk mengukur daya ledak otot tenaga eksplosif. Hasil yang dicatat adalah selisih raihan loncatan dikurangi raihan tegak.

5. Tes Lari 1200 meter untuk Putra dan Tes Lari 1000 meter untuk Putri.

Tes ini bertujuan untuk mengukur daya tahan jantung, peredaran darah dan pernafasan, selain itu untuk mengetahui tingkat kebugaran jasmani anak usia 16-19 tahun. Pengambilan waktu dilaksanakan pada saat bendera diangkat sampai pelari tepat melewati garis finish.

Pemilihan tes ini dikarenakan tes ini telah lazim digunakan dan berlaku untuk seluruh wilayah Indonesia. Selain itu tes ini relatif mudah untuk dilakukan dengan instrument yang telah teruji validitas dan reliabilitasnya sehingga layak digunakan untuk pengambilan data penelitian.Tes kebugaran jasmani Indonesia ini telah disepakati dan ditetapkan menjadi suatu instrumen yang berlaku di seluruh Indonesia, 
oleh karena telah teruji reliabilitas dan validitasnya. Tes ini memiliki validitas sebesar 0.720 , sedangkan reliabilitas sebesar 0.920 .

\section{E. TEKNIK PENGUMPULAN DATA}

Data yang akan di jaring untuk keperluan penelitian ini adalah data tentang tingkat status kebugaran jasmani atlet dengan tes pengukurannya sebagai berikut :
a) Lari 60 meter
b) Tes gantung siku tekuk
c) Baring duduk
d) Loncat tegak
e) Lari 1200m untuk putra dan 1000m untuk putri

\section{F. HASIL DAN PEMBAHASAN}

Berdasarkan hasil penelitian yang telah dilakukan, maka hasil penelitian disajikan dalam bentuk penyajian data yang sesuai dengan hasil pengukuran yang dilakukan sebelumnya. Penelitian ini bertujuan untuk mengetahui tingkat kebugaran jasmani atlet Karate Dojo Redland Halong Usia 16-19 tahun. Berjumlah 30 atlet terdiri dari 15 putra dan 15 putri. Berdasarkan analisis menunjukkan bahwa: Tingkat Kebugaran Jasmani atlet Karate Dojo Redland Halong yang berkategori baik sekali 0 orang atau $0 \%$, baik 18 orang atau $60 \%$, sedang 12 orang atau $40 \%$, kurang 0 orang atau $0 \%$ dan kurang sekali 0 orang atau $0 \%$. Hasil tes bisa dilihat pada tabel sebagai berikut:

Tabel. 1 Hasil Tes Kebugaran Jasmani Atlet Putra

\begin{tabular}{|c|c|c|c|c|c|c|c|c|c|c|}
\hline \multirow[b]{2}{*}{ No } & \multirow[b]{2}{*}{ Nama } & \multirow[b]{2}{*}{ Usia } & \multirow[b]{2}{*}{$\mathbf{J K}$} & \multicolumn{5}{|c|}{ Nilai TKJI } & \multirow[b]{2}{*}{ Nilai } & \multirow[b]{2}{*}{ Status } \\
\hline & & & & $\begin{array}{l}\text { Lari } \\
60 \mathrm{~m}\end{array}$ & $\begin{array}{c}\text { Gantung } \\
\text { Angkat } \\
\text { Tubuh }\end{array}$ & $\begin{array}{l}\text { Baring } \\
\text { Duduk }\end{array}$ & $\begin{array}{c}\text { Loncat } \\
\text { Tegak }\end{array}$ & $\begin{array}{c}\text { Lari } \\
1200 \mathrm{~m}\end{array}$ & & \\
\hline 1 & JAS & 17 & $\mathrm{~L}$ & 6"18 & 11 & 37 & 259 & 5'27'89 & 17 & Sedang \\
\hline 2 & MF & 16 & $\mathrm{~L}$ & 7"32 & 7 & 40 & 250 & 4'25"63 & 17 & Sedang \\
\hline 3 & MFA & 16 & $\mathrm{~L}$ & $6 " 68$ & 8 & 45 & 255 & 4'46"88 & 18 & Baik \\
\hline 4 & $\mathrm{CH}$ & 16 & $\mathrm{~L}$ & $7 " 60$ & 10 & 44 & 257 & 5'11"38 & 18 & Baik \\
\hline 5 & JES & 19 & $\mathrm{~L}$ & 6"82 & 10 & 47 & 272 & 5'10"02 & 20 & Baik \\
\hline 6 & YR & 19 & $\mathrm{~L}$ & 7"70 & 12 & 44 & 271 & 6'25"24 & 18 & Baik \\
\hline 7 & AFL & 17 & $\mathrm{~L}$ & 6"19 & 11 & 41 & 252 & 5'77'80 & 18 & Baik \\
\hline 8 & RKA & 17 & $\mathrm{~L}$ & 7"35 & 10 & 42 & 258 & 4'25"69 & 19 & Baik \\
\hline 9 & AW & 16 & $\mathrm{~L}$ & 6"63 & 11 & 42 & 256 & 4'56"87 & 19 & Baik \\
\hline 10 & JS & 17 & $\mathrm{~L}$ & 7"71 & 9 & 40 & 261 & 5'12"88 & 18 & Baik \\
\hline 11 & APL & 18 & $\mathrm{~L}$ & 6"87 & 9 & 41 & 257 & 6'47"29 & 17 & Sedang \\
\hline 12 & ASP & 18 & $\mathrm{~L}$ & 7"78 & 11 & 43 & 259 & 5'12"22 & 18 & Baik \\
\hline 13 & $\mathbf{A R}$ & 16 & $\mathrm{~L}$ & $6 " 58$ & 8 & 43 & 257 & 6'55"70 & 16 & Sedang \\
\hline 14 & FPS & 19 & $\mathrm{~L}$ & $7 " 46$ & 10 & 42 & 240 & $5^{\prime} 12^{\prime} 82$ & 17 & Sedang \\
\hline 15 & MF & 18 & $\mathrm{~L}$ & 7"78 & 11 & 43 & 259 & 5'12"22 & 18 & Baik \\
\hline
\end{tabular}


Nilai pada grafik. 12 di atas merupakan hasil TKJI atlet putra, disimpulkan bahwa secara keseluruhan diketahui atlet putra yang memperoleh data baik sekali 0\% (0 atlet), baik 67\% (10 atlet), sedang sebanyak 33\% (5 atlet), kurang 0\% (0 atlet), kurang sekali 0\% (0 atlet).

Tabel.2 Hasil Tes Kebugaran Jasmani Atlet Putri

\begin{tabular}{|c|c|c|c|c|c|c|c|c|c|c|}
\hline \multirow[b]{2}{*}{ No } & \multirow[b]{2}{*}{ Nama } & \multirow[b]{2}{*}{ Usia } & \multirow[b]{2}{*}{ JK } & \multicolumn{5}{|c|}{ Nilai TKJI } & \multirow[b]{2}{*}{ Nilai } & \multirow[b]{2}{*}{ Status } \\
\hline & & & & Lari 60m & $\begin{array}{c}\text { Gantung } \\
\text { Siku Tekuk }\end{array}$ & $\begin{array}{l}\text { Baring } \\
\text { Duduk }\end{array}$ & $\begin{array}{c}\text { Loncat } \\
\text { Tegak }\end{array}$ & $\begin{array}{c}\text { Lari } \\
1000 m\end{array}$ & & \\
\hline 1 & FPS & 16 & $\mathrm{P}$ & $10 " 00$ & 11 & 37 & 259 & $10^{\prime} 10^{\prime \prime} 95$ & 14 & Sedang \\
\hline 2 & CFW & 16 & $\mathrm{P}$ & $8 " 42$ & 7 & 40 & 250 & 7'15"72 & 16 & Baik \\
\hline 3 & MW & 17 & $\mathrm{P}$ & $9 " 25$ & 8 & 45 & 255 & 7'29"20 & 15 & Sedang \\
\hline 4 & DMJ & 16 & $\mathrm{P}$ & 9"70 & 10 & 44 & 257 & 9'17"03 & 16 & Sedang \\
\hline 5 & MEP & 16 & $\mathrm{P}$ & 8"61 & 10 & 47 & 272 & 7'10"80 & 18 & Sedang \\
\hline 6 & MJN & 16 & $\mathrm{P}$ & 9"12 & 12 & 44 & 271 & 8'04"85 & 17 & Sedang \\
\hline 7 & LSS & 16 & $\mathrm{P}$ & $8 " 65$ & 11 & 41 & 252 & 7'20'50 & 17 & Sedang \\
\hline 8 & AH & 18 & $\mathrm{P}$ & $9 " 13$ & 10 & 42 & 258 & 7'55"79 & 16 & Sedang \\
\hline 9 & ICC & 18 & $\mathrm{P}$ & $8 " 71$ & 11 & 42 & 256 & 7'32"76 & 16 & Sedang \\
\hline 10 & EJR & 19 & $\mathrm{P}$ & $8 " 45$ & 9 & 40 & 261 & 7'25"64 & 17 & Sedang \\
\hline 11 & SNA & 17 & $\mathrm{P}$ & $11 " 03$ & 9 & 41 & 257 & 11 '02"31 & 15 & Sedang \\
\hline 12 & DK & 16 & $\mathrm{P}$ & 9"57 & 11 & 43 & 259 & $8^{\prime} 58^{\prime \prime 62}$ & 16 & Sedang \\
\hline 13 & STY & 18 & $\mathrm{P}$ & $9 " 82$ & 8 & 43 & 257 & 9'23"70 & 15 & Sedang \\
\hline 14 & $\mathbf{Z L}$ & 17 & $\mathrm{P}$ & $8 " 81$ & 10 & 42 & 240 & 7'16"42 & 17 & Baik \\
\hline 15 & KB & 16 & $\mathrm{P}$ & 8"64 & 11 & 43 & 259 & $6 ' 59 " 43$ & 17 & Sedang \\
\hline
\end{tabular}

Sedangkan untuk nilai pada grafik 4.2 di atas merupakan hasil TKJI atlet putri, disimpulkan bahwa secara keseluruhan diketahui atlet putri yang memperoleh data baik sekali $0 \%$ (0 atlet), baik 13\% (2 atlet), sedang sebanyak 87\% (13 atlet), kurang 0\% (0 atlet), kurang sekali 0\% (0 atlet). Secara keseluruhan Tingkat Kebugaran Jamani atlet Karate Dojo Redland Halong adalah sedang, ini dikarenakan kurangnya latihan kebugaran yang di berikan, sedangkan latihan yang sering di berikan adalah latihan tehnik karena sudah mendekati Kejurda Redland 2019 di Ambon, selain itu para atlet mulai giat berlatih hanya beberapa bulan sebelum perlombaan dimulai.

Kebugaran jasmani seseorang menentukan kemampuan fisiknya dalam kehidupan sehari hari. Semakin tinggi kebugaran jasmani seseorang semakin tinggi pula kemampuan kerja fisik atau aktivitasnya, sehingga semakin tinggi pula kesempatan untuk mendapatkan juara karena memiliki kebugaran jasmani yang baik.

\section{Lari 60 meter (usia16-19 tahun)}

a. Putra

Tingkat Kebugaran Jasmani atlet Karate Dojo Redland Halong berdasarkan komponen kecepatan yang berkategori baik sekali 46,67\% (7 atlet), baik 53,33\% (8 atlet), sedang sebanyak $0 \%$ (0 atlet), kurang $0 \%$ (0 atlet), kurang sekali $0 \%$ (0 atlet). 
b. Putri

Tingkat Kebugaran Jasmani atlet Karate Dojo Redland Halong berdasarkan komponen kecepatan yang berkategori baik sekali 20\% (3 atlet), baik 80\% (12 atlet), sedang sebanyak $0 \%$ (0 atlet), kurang 0\% (0 atlet), kurang sekali 0\% (0 atlet).

\section{Gantung Angkat Tubuh (Putra) / Gantung Siku Tekuk ( Putri)}

a. Putra

Tingkat Kebugaran Jasmani atlet Karate Dojo Redland Halong berdasarkan komponen kecepatan yang berkategori baik sekali 80\% (12 atlet), baik 20\% (3 atlet), sedang sebanyak 0\% (0 atlet), kurang 0\% (0 atlet), kurang sekali 0\% (0 atlet).

b. Putri

Tingkat Kebugaran Jasmani atlet Karate Dojo Redland Halong berdasarkan komponen kecepatan yang berkategori baik sekali 20\% (3 atlet), baik 80\% (12 atlet), sedang sebanyak 0\% (0 atlet), kurang 0\% (0 atlet), kurang sekali 0\% (0 atlet).

\section{Baring Duduk}

a. Putra

Tingkat Kebugaran Jasmani atlet Karate Dojo Redland Halong berdasarkan komponen kecepatan yang berkategori baik sekali 0\% (0 atlet), baik 53,33\% (8 atlet), sedang sebanyak 46,67\% (7 atlet), kurang 0\% (0 atlet), kurang sekali 0\% (0 atlet).

b. Putri

Tingkat Kebugaran Jasmani atlet Karate Dojo Redland Halong berdasarkan komponen kecepatan yang baik sekali 46,67\% (8 atlet), baik 53,33\% (7 atlet), sedang sebanyak 0\% (0 atlet), kurang 0\% (0 atlet), kurang sekali 0\% (0 atlet).

\section{Loncat Tegak}

a. Putra

Tingkat Kebugaran Jasmani atlet Karate Dojo Redland Halong berdasarkan komponen kecepatan yang berkategori baik sekali 0\% (0 atlet), baik 20\% (3 atlet), sedang sebanyak $73,33 \%$ (11 atlet), kurang 6,67\% (1 atlet), kurang sekali 0\% (0 atlet).

\section{b. Putri}

Tingkat Kebugaran Jasmani atlet Karate Dojo Redland Halong berdasarkan komponen kecepatan yang berkategori baik sekali 0\% (0 atlet), baik 13,33\% (2 atlet), sedang sebanyak 40\% (6 atlet), kurang 7\% (46,67 atlet), kurang sekali 0\% (0 atlet).

\section{1200m (Putra) / 1000 meter (Putri)}

\section{a. Putra}

Tingkat Kebugaran Jasmani atlet Karate Dojo Redland Halong berdasarkan komponen kecepatan yang berkategori baik sekali 0\% (0 atlet), baik 13,33\% (2 atlet), sedang sebanyak 53,33\% (8 atlet), kurang 3\% (20 atlet), kurang sekali 6,67\% (1 atlet).

b. Putri 
Tingkat Kebugaran Jasmani atlet Karate Dojo Redland Halong berdasarkan komponen kecepatan yang berkategori baik sekali 0\% (0 atlet), baik 0\% (0 atlet), sedang sebanyak 0\% (0 atlet), kurang 26,67\% (4 atlet), kurang sekali 73,33\% (11 atlet).

Dari hasil di atas dapat di ketahui komponen Kebugaran Jasmani atlet putra dan putri Karate Dojo Redland Halong yang tebaik adalah komponen kekuatan otot perut ini disebabkan atlet Karate Dojo Redland Halong sudah berlatih kekuatan otot perut karena selalu melakukan latihan sit-up setiap pemanasan, sedangkan komponen Kebugaran Jasmani yang terburuk adalah komponen daya tahan paru jantung, latihan daya tahan paru memang jarang di berikan.

\section{G. KESIMPULAN}

Dari uraian pada bab IV sudah diketahui bahwa Tingkat Kebugaran Jasmani Atlet Putra Dojo Redland Halong termasuk dalam kategori baik sedangkan untuk Atlet Putri Dojo Redland Halong termasuk dalam kategori sedang . Secara rinci dapat diuraikan bahwa tingkat kebugaran jasmani atlet putra dengan kategori baik sekali 0\% (0 atlet), baik 67\% (10 atlet), sedang sebanyak 33\% (5 atlet), kurang 0\% (0 atlet), kurang sekali 0\% (0 atlet). Sedangkan untuk atlet putri dapat diuraikan bahwa tingkat kebugaran jasmani dengan kategori baik sekali 0\% (0 atlet), baik 13\% (2 atlet), sedang sebanyak 87\% (13 atlet), kurang $0 \%$ (0 atlet), kurang sekali $0 \%$ (0 atlet).

\section{DAFTAR PUSTAKA}

Juniar, M. A., \& Dr. Wijono, M. P. (2019). Profil Kondisi Fisik Atlet Karate Persiapan Porprov Kabupaten Tuban Tahun 2019. Prestasi Olahraga, 2(1).

Khalili Moghaddam, G., \& Lowe, C. R. (2019). Physical Activity. In Springerbriefs In Applied Sciences And Technology. Https://Doi.Org/10.1007/978-3-030-01557-2_2

Rahmat, \& Permana. (2016). Penguasaan Rangkaian Tes Kebugaran Jasmani Indonesia (Tkji) Melalui Diskusi Dan Simulasi. Jurnal Refleksi Edukatika.

Sugiyono. (2015). Metode Penelitian. Metode Penelitian. 